\title{
Guidance Scheme for Paths without Temporary Restrictions Using the Krick Felix Model Boat under the Influence of Sea Currents
}

Leidys Miranda Jiménez / lemiranda@uclv.cu

Yunier Valeriano Medina / yunierv@uclv.edu.cu

Ángel A. Camero Álvarez / acamero@uclv.edu.cu

Universidad Central Marta Abreu de Las Villas, Santa Clara-Cuba

ABSTRACT The autonomous surface vehicles are composed of a guidance, navigation, and control systems where the first one plays an important role in missions without human intervention. This article presents the design of a guidance system made of an I-LOS controller, where its purpose is to achieve the convergence and the precise following of straight paths, regardless of the sea currents presence. The controller gains adjustment is performed according to the vehicle features and the geometry of the path to follow. The proposed guidance algorithm is assessed through simulation, obtaining favorable results.

KEYWORDS Autonomous surface vehicles; guiding; I-LOS controller.

Esquema de guiado para el seguimiento de caminos sin restricciones temporales por parte del barco Krick Felix bajo la influencia de las corrientes marinas

RESUMEN Los vehículos autónomos de superficie están compuestos por un sistema de guiado, un sistema de navegación y un sistema de control, el primero de ellos juega un papel vital en el cumplimiento de misiones sin intervención humana. Este artículo presenta el diseño de un esquema guiado, formado por un controlador I -LOS, que tiene como finalidad lograr la convergencia y el seguimiento preciso de caminos rectos, a pesar de la presencia de las corrientes marinas. El ajuste de las ganancias del controlador se realiza de acuerdo con las características del vehículo y la geometría del camino a seguir. El algoritmo de guiado propuesto se evalúa mediante una simulación, con resultados favorables.

PALABRAS CLAVE Vehículos autónomos de superficie; guiado; controlador I-LOS.
Esquema de orientação para rastreamento de caminhos sem restrições temporárias pelo navio Krick Felix sob a influência de correntes marinhas

RESUMO Os veículos autônomos de superfície são compostos por um sistema de orientação, um sistema de navegação e um sistema de controle, o primeiro deles desempenha um papel vital no cumprimento de missões sem intervenção humana. Este artigo apresenta o projeto de um esquema guiado, composto por um controlador I-LOS, que visa alcançar a convergência e o rastreamento preciso de caminhos retos, apesar da presença de correntes marinhas. $\mathrm{O}$ ajuste dos ganhos do controlador é feito de acordo com as características do veículo e a geometria do caminho a ser seguido. O algoritmo de guiado proposto é avaliado através de simulação, com resultados favoráveis.

PALAVRAS-CHAVE Veículos autônomos de superfície; guiado; controlador I-LOS. 


\section{Introduction}

Marine vehicles have several applications, they are widely used in recreative activities — such as fishing-, in military applications, and as a means of transport. The term includes ships, semi-submersibles, submarines, Remotely Operated Vehicles [ROV], Autonomous Underwater Vehicles [AUV], torpedoes and other propelled and energized structures able to navigate (Fossen, 2011).

The so-called Unmanned Surface Vehicles [USV] have as a main advantage the fact of not requiring human intervention, allowing them to perform missions with higher efficiency. Every vehicle in this category has a movement control system to operate autonomously; this system is composed of guidance, navigation, and control systems. In this research paper, our interest is in the guidance system since its main objective is to provide the state of the necessary references - position, speed, and acceleration - to the controller in a continuous way to ensure the vehicle always goes through the precise path (Lekkas, 2014).

The path following without temporary restrictions is a movement control scenario where the control objective is to converge and follow a geometric path previously defined without considering temporary restrictions. The guidance and control solutions proposed for this scenario are several (Breivik \& Fossen, 2009), where an important number of works employ the guidance strategy known as Line of Sight [LOS] (Breivik \& Fossen, 2009; Fossen, 2002).

The Automation, Robotics, and Sensing Group [GARP, Grupo de Automatización, Robótica y Percepción] of the Universidad Central Marta Abreu de Las Villas (Cuba) works in the study of marine vehicles, specifically in modelling, control, and guidance topics. Former research works performed by the group demonstrate that the LOS strategy is not capable to ensure the precision during the path following with sea currents; hence, an addition of an integral action in the guidance law is proposed to counteract the effect of these currents during the path following process using the HRC-AUV submersible vehicle (Hernández, Valeriano, \& Fernández, 2016; Valeriano, Hernández, \& Hernández, 2015; Miranda, Valeriano, \& Hernández, 2017).

One of the current research interests of the group is focused on the development of the Krick Felix robotic ship; the objective regarding this vehicle is to have a mockup where control, guidance, and navigation algorithms can be tested to extend the maneuverability possibilities during several missions. The Krick Felix is an underactuated vehicle because it has less control inputs than degrees of freedom to control. This, together with the non-linearity of its dynamics and to the effects of the sea currents makes necessary to use a guidance solution within it to ensure precision during the following of straight paths.

\section{Introducción}

Los vehículos marinos poseen variadas aplicaciones, son muy utilizados en actividades recreativas - como la pesca-, en aplicaciones militares y como medio de transporte. El término vehículos marinos incluye barcos, semi-sumergibles, submarinos, vehículos subacuáticos operados remotamente [Remotely Operated Vehicles, ROV] o de manera autónoma [Autonomous Underwater Vehicles, AUV], torpedos y otras estructuras propulsadas y energizadas, capacitadas para navegar (Fossen, 2011).

Los vehículos autónomos de superficie [Unmanned Surface Vehicles, USV] tienen como principal ventaja el no requerir de intervención humana, lo que les permite realizar misiones con mayor grado de eficiencia. Toda embarcación de este tipo presenta un sistema de control de movimiento que le permite operar de forma autónoma, el cual está compuesto por un sistema de guiado, un sistema de navegación y un sistema de control. En esta investigación el interés recae en el sistema de guiado, ya que su objetivo fundamental es proporcionar de forma continua al controlador el estado de las referencias necesarias - posición, velocidad y aceleración- para que el vehículo recorra la ruta precisa (Lekkas, 2014).

El seguimiento de camino sin restricciones temporales [path following constituye un escenario de control de movimiento, donde el objetivo de control es converger y seguir un camino geométrico previamente definido, sin considerar restricción temporal alguna. Las soluciones de guiado y control que se proponen para este tipo de escenario son numerosas (Breivik \& Fossen, 2009), un número importante de trabajos emplea la estrategia de guiado conocida como línea de visión [Line of Sight, LOS] (Breivik \& Fossen, 2009; Fossen, 2002).

El Grupo de Automatización, Robótica y Percepción [GARP] de la Universidad Central Marta Abreu de las Villas (Cuba) trabaja en el estudio de vehículos marinos, específicamente en temas de modelado, control y guiado; investigaciones precedentes de este grupo demuestran que la estrategia LOS no es capaz de asegurar la precisión durante el seguimiento de caminos en presencia de corrientes marinas, por lo que proponen incorporar una acción integral en la ley de guiado para contrarrestar el efecto de las corrientes marinas durante el seguimiento de caminos por parte del vehículo sumergible HRC-AUV (Hernández, Valeriano, \& Fernández, 2016; Valeriano, Hernández, \& Hernández, 2015; Miranda, Valeriano, \& Hernández, 2017).

Una línea actual de investigación del grupo está enmarcada en el desarrollo del barco robótico Krick Felix; el propósito con este vehículo es contar con una maqueta donde se puedan probar algoritmos de control, guiado y navegación, con el fin de extender las posibilidades de maniobrabilidad durante el desarrollo de diferentes misiones. El Krick Felix es un vehículo sub-actuado, pues posee menos entradas de control que grados de libertad a controlar, lo cual, unido a las no linealidades que caracterizan su dinámica y a las afectaciones que provocan las corrientes marinas, hace necesario utilizar en él una solución de guiado que asegure precisión durante el seguimiento de caminos rectos. 


\section{Modelo dinámico}

El Krick Felix (Figura 1) es un modelo a escala de un buque del puerto de Hamburgo (Alemania); para su movimiento, cuenta con un motor eléctrico, una propela acoplada y el equipamiento necesario que lo convierte en un bote robótico. Las principales especificaciones geométricas de la embarcación las cuales tienen incidencia en el modelado y control del vehículo- se muestran en la TABLA 1.

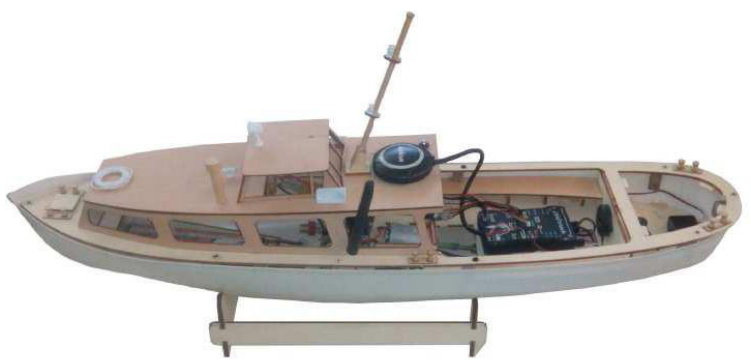

Figure 1. Krick Felix

Tradicionalmente, los movimientos de traslación y posición de un vehículo marino se representan utilizando varias expresiones, lo que trae como resultado complicados modelos formados por cientos de elementos. Las maniobras que se pueden realizar en las embarcaciones marinas abarcan los movimientos en los seis grados de libertad [6 GDL], los cuales están determinados por los desplazamientos independientes y por las rotaciones que especifican totalmente la posición y orientación del vehículo (Fossen, 2011).

En la TABLA 2 se expone la nomenclatura estándar -Notación SNAME (1950) - empleada en la descripción del movimiento de los vehículos marinos, donde la guiñada es el grado de libertad más importante en el diseño de controladores de dirección.

Table 2. Geometric, physical, and inertial data of the KrickFelix / Datos geométricos, físicos e inerciales del Krick Felix

\begin{tabular}{llll}
\hline $\begin{array}{l}\text { Translation / } \\
\text { Translación }\end{array}$ & $\begin{array}{l}\text { Force / } \\
\text { Fuerza }\end{array}$ & $\begin{array}{l}\text { Linear speed / } \\
\text { Velocidad lineal }\end{array}$ & $\begin{array}{l}\text { Position / } \\
\text { Posición }\end{array}$ \\
\hline Surge / Avance & $X$ & $u$ & $x$ \\
$\begin{array}{l}\text { Sway / Desplaza- } \\
\text { miento lateral }\end{array}$ & $Y$ & $v$ & $y$ \\
Heave / Arfada & $Z$ & $w$ & \\
Rotation / & Moment / & $\begin{array}{l}\text { Angular speed / } \\
\text { Velocidad angular }\end{array}$ & $\begin{array}{l}\text { Angle / } \\
\text { Angulo }\end{array}$ \\
Rollión / Balanceo & $K$ & $p$ & $\phi$ \\
Pitch / Cabeceo & $M$ & $q$ & $\theta$ \\
Yaw / Guinada & $N$ & $r$ & $\psi$ \\
\hline
\end{tabular}

El movimiento de un vehículo marino puede ser descrito a través de dos sistemas de coordenadas (FIGURA 2): uno respecto del vehículo y otro inercial referido a tierra.

El primero de ellos es un sistema de coordenadas móvil llamado Sistema del Barco. El origen de este sistema $\left(\mathrm{O}_{\mathrm{b}}\right)$ se sitúa en el centro de gravedad del vehículo $(\mathrm{CG})$. Los ejes $\mathrm{x}_{0}, \mathrm{y}_{0} \mathrm{y} \mathrm{z}_{0}$ coinciden con los ejes principales de inercia.

\section{II.Dynamic Model}

TheKrickFelix (FIgure1) is a scale model of a Hamburg harborship; for its movement, it has an electric engine, a coupled propeller, and the necessary equipment to make it a robotic ship. The main geometric specifications of the ship - which have incidence in the modelling and control of it - are shown in TABLE 1.

Table 1. Geometric, physical, and inertial data of the KrickFelix / Datos geométricos, físicos e inerciales del Krick Felix

\begin{tabular}{crr}
\hline $\begin{array}{c}\text { Parameter / } \\
\text { Parámetro }\end{array}$ & $\begin{array}{r}\text { Description/ } \\
\text { Descripción }\end{array}$ & $\begin{array}{r}\text { Value / } \\
\text { Valor }\end{array}$ \\
\hline $\mathrm{M}$ & Mass / Masa & $0.8 \mathrm{~kg}$ \\
$u_{0}$ & Cruising speed / Velocidad crucero & $1.2 \mathrm{~m} / \mathrm{s}$ \\
$\mathrm{L}$ & Length / Largo & $0.634 \mathrm{~m}$ \\
$\mathrm{~B}$ & Width / Ancho & $0.128 \mathrm{~m}$ \\
$\mathrm{R}$ & Ratio / Radio & $0.317 \mathrm{~m}$ \\
$\mathrm{~T}$ & Draft / Calado & $0.035 \mathrm{~m}$ \\
$I_{z}$ & Moment of inertia / Momento de inercia & $0.032 \mathrm{kgm}^{2}$ \\
\hline
\end{tabular}

Traditionally, the translation and position movements in a marine vehicle are represented using several expressions, which entails complicated models formed by hundreds of elements. The maneuvers achieved with marine vehicles are related with 6 degrees of freedom movements, which are determined by the independent movements and by the rotations specifying the vehicle position and orientation (Fossen, 2011).

In TABLE 2, we present the standard nomenclature - SNAME notation (1950) - employed in the movement description of marine vehicles, where the yawing is the most important degree of freedom in the design of direction controllers.

The movement of a marine vehicle can be described through two coordinate systems (see Figure 2): one regarding the vehicle and the other inertial relative to ground.

The first of them is a mobile coordinate system called boat system. The origin of this system $\left(\mathrm{O}_{\mathrm{b}}\right)$ is in the vehicle's center of gravity. The axis $\mathrm{x}_{0}, \mathrm{y}_{0}$, and $\mathrm{z}_{0}$ coincide with the main inertial axis.

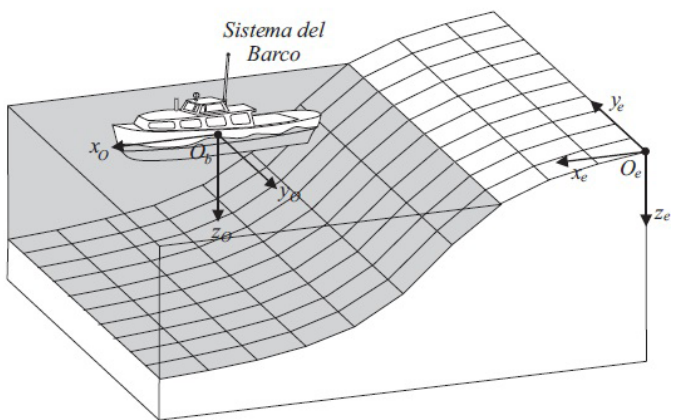

Figure 2. Coordinate systems / Sistemas de coordenadas 
For surface vehicles, only the horizontal plane is considered by using a model with three degrees of freedom. As per the boats float $(z \approx 0)$ and they are lengthy and laterally metacentric $(\phi=\theta=\phi=\theta \approx 0)$, the heave, roll, and pitch dynamics are discarded. The speed, position, forces, and moments vectors defining the movement of a ship in the three degrees of freedom are described by equations 1, 2 y 3 (Fossen, 2011):

$$
\begin{gathered}
v=[u, v, w]^{T} \\
\eta=[x, y, \psi]^{T} \\
\tau=[X, Y, N]^{T}
\end{gathered}
$$

where,

$v$ represents the linear and angular speed vector with coordinates in the vehicle system;

$\eta \quad$ is the position and orientation vector with coordinates in the reference system fixed in the ground; and

$\tau$ is used to represent the forces and moments acting in the vehicle over its coordinate system.

The kinematic equations are expressions that relate the derivative of the position and speed in a rigid body. Such equations can be expressed in matrices (see (4) and (5)) by using the Euler angles transformations (Fossen \& Ross, 2006):

$$
\dot{\eta}=R(\eta) v
$$

where,

$R(\eta)$ is the transformation matrix of the boat system to the inertial reference system, defined as follow:

$$
R(\eta)=\left[\begin{array}{ccc}
c \psi & -s \psi & 0 \\
s \psi & c \psi & 0 \\
0 & 0 & 1
\end{array}\right]
$$

The general model of a marine vehicle is influenced by the forces and hydrostatic and hydrodynamic moments, effects mathematically expressed through the so-called added mass and damping terms, and through the restoring forces. Considering this, the non-linear equation describing the movement of a USV is expressed as equation (6) indicates (Fossen, 2002; Fossen, 2011; Fossen, 1994).

$$
\frac{M_{R B} \dot{V}+C_{R B}(v) V}{\text { rígid body terms }}+\frac{M_{A} \dot{V}+C_{A}(v) V+D(V) V}{\text { hydrodynamics terms }}+\frac{(g(\eta)}{\text { hydrostatics terms }}=\tau
$$

The sea currents are one of the main alterations affecting the marine vehicles during the navigation. For this reason
Para vehículos de superficie se trabaja solamente en el plano horizontal, utilizando un modelo de 3 GDL. Como los barcos flotan $(\mathrm{z} \approx 0)$ y son longitudinal y lateralmente metacéntricos $(\phi$ $=\theta=\phi=\theta \approx 0$ ), se descartan las dinámicas de arfada, balanceo y cabeceo. Los vectores de velocidad, posición, fuerzas y momentos que definen el movimiento de una embarcación en los 3 GDL se describen mediante las ecuaciones 1, 2 y 3 (Fossen, 2011), así :

$$
\begin{aligned}
& v=[u, v, w]^{T} \\
& \eta=[x, y, \psi]^{T} \\
& \tau=[X, Y, N]^{T}
\end{aligned}
$$

donde,

$v$ representa al vector de velocidad lineal y angular con coordenadas en el sistema del vehículo;

$\eta$ denota el vector de posición y orientación con coordenadas en el sistema de referencia fijo en tierra; y

$\tau$ se utiliza para representar las fuerzas y momentos que actúan sobre el vehículo en su sistema de coordenadas.

Las ecuaciones cinemáticas son aquellas expresiones que relacionan la derivada de la posición y la velocidad de un cuerpo rígido. Dichas ecuaciones se pueden expresar en forma matricial utilizando las transformaciones de ángulos de Euler (Fossen, 2006), así:

$$
\dot{\eta}=R(\eta) v
$$

donde:

$R(\eta)$ es la matriz de transformación del sistema del barco al sistema de referencia inercial, y queda definida como:

$$
R(\eta)=\left[\begin{array}{ccc}
c \psi & -s \psi & 0 \\
s \psi & c \psi & 0 \\
0 & 0 & 1
\end{array}\right]
$$

El modelo general de un vehículo marino se encuentra influenciado por las fuerzas y momentos hidrostáticos e hidrodinámicos, efectos que se expresan matemáticamente mediante los denominados términos de masas añadidas, de amortiguamiento y las fuerzas restauradoras. Teniendo esto en consideración la ecuación no lineal que describe el movimiento de un USV se expresa como se indica en la ecuación (6) (Fossen, 2002; Fossen, 2011; Fossen, 1994).

$$
\frac{M_{R B} \dot{V}+C_{R B}(v) v}{\text { cuerpo rígido }}+\frac{M_{A} \dot{V}+C_{A}(v) v+D(v) v}{\text { términos hidrdinámicos }}+(g(\eta)=\tau
$$

Las corrientes marinas constituyen una de las principales perturbaciones que afectan a los vehículos marinos de superficie durante la navegación, por ello se consideran en este caso como perturbaciones externas y actuantes en cada uno de los ejes del sistema de coordenadas del vehículo $\left(\mathrm{x}_{0}, \mathrm{y}_{0}, \mathrm{z}_{0}\right)$. Por ello, 
con el objetivo de alcanzar una mayor precisión en el modelo del Krick Felix, a la ecuación (6) se le incorporan los términos relativos a las corrientes marinas quedando como se indica en la ecuación (7).

$$
M \dot{v}_{r}+C\left(v_{r}\right) v_{r}+D\left(v_{r}\right) v_{r}+g(\eta)=\tau
$$

donde,

$M=M_{R B}+M_{A}$ es la matriz de inercia incluyendo las masas añadidas;

$C=C_{R B}\left(v_{\mathrm{r}}\right)+\mathrm{C}_{\mathrm{A}}\left(v_{\mathrm{r}}\right)$ es la matriz que incluye los términos de Coriolis del cuerpo rígido y de las masas añadidas;

$\mathrm{D}\left(v_{\mathrm{r}}\right)$ es la matriz de amortiguamiento;

$\mathrm{g}(\boldsymbol{\eta})$ es el vector de fuerzas gravitacionales y de flotabilidad;

$\tau=\left[\tau_{\mathrm{x}}, \tau_{\mathrm{y}}, \tau_{\mathrm{n}}\right]^{\mathrm{T}}$ representa el vector de fuerzas y momentos de las entradas de control; $y$

$v_{\mathrm{r}}$ es la velocidad relativa del vehículo con respecto a las corrientes.

En el caso de vehículos que navegan en la superficie, el vector $\mathrm{g}(\eta)$ se considera cero. La estructura de cada una de estas matrices y vectores para el vehículo Krick Felix ha sido determinada por el GARP en investigaciones anteriores (Valeriano, García, \& Balanza, 2017).

El término $\mathrm{v}_{\mathrm{r}}$ representa la velocidad relativa del vehículo con respecto a las corrientes (8) y queda definido así.

$$
\mathrm{v}_{\mathrm{r}}=\mathrm{v}^{-} \mathrm{v}_{\mathrm{c}} \quad(8)
$$

donde,

$v$ es el vector velocidad del vehículo definido en (1); y $v_{c}=\left[u_{c}, v_{c}, 0\right]^{T}$ es el vector que representa la velocidad de las corrientes referido al origen del sistema del vehículo, considerando que las mismas no generan movimientos rotacionales en el vehículo.

Las componentes $u_{c}$ y $v_{c}$ referidas al sistema inercial pueden ser calculadas a partir del módulo de la velocidad de las corrientes $\left(V \partial\right.$ y del ángulo de dirección que poseen $\left(\beta_{c}\right)$, así:

$$
\begin{gathered}
u_{c}^{E}=V_{C} \cos \beta_{c} \\
v_{c}^{E}=V_{C} \operatorname{sen} \beta_{c} .
\end{gathered}
$$

Para obtener las componentes referidas al $O_{b}$ es necesario aplicar las transformaciones de coordenadas en función de los ángulos de Euler (Fossen, 2011), quedando de la forma:

$$
\left[\begin{array}{l}
u_{c} \\
v_{c}
\end{array}\right]=\left[\begin{array}{cc}
\cos \psi & \sin \psi \\
-\sin \psi & \cos \psi
\end{array}\right]\left[\begin{array}{l}
u_{c}^{E} \\
v_{c}^{E}
\end{array}\right]
$$

Luego, aplicando identidades trigonométricas, es posible desarrollar las ecuaciones (12) y (13), así:

$$
\begin{aligned}
& u_{c}=V_{C} \cos \left(\beta_{c}-\psi\right) \\
& v_{c}=V_{C} \sin \left(\beta_{c}-\psi\right)
\end{aligned}
$$

and for our study, we considered them as external perturbations acting on each one of the axis in the vehicle coordinate system $\left(\mathrm{x}_{0}, \mathrm{y}_{0}, \mathrm{z}_{0}\right)$. Consequently, pursuing the objective to reach a larger precision in the modelling of the Krick Felix, the relative terms to the sea currents were added to equation (6), resulting in equation (7).

$$
M \dot{v}_{r}+C\left(v_{r}\right) v_{r}+D\left(v_{r}\right) v_{r}+g(\eta)=\tau,
$$

where,

$M=M_{R B}+M_{A}$ is the inertia matrix including the added masses;

$C=C_{R B}\left(v_{\mathrm{r}}\right)+\mathrm{C}_{\mathrm{A}}\left(v_{\mathrm{r}}\right)$ is the matrix including the Coriolis terms of the rigid body and the added masses;

$\mathrm{D}\left(v_{\mathrm{r}}\right)$ is the damping matrix;

$\mathrm{g}(\boldsymbol{\eta})$ is the vector of gravitational forces and buoyancy; $\tau=\left[\tau_{x}, \tau_{y}, \tau_{n}\right]^{T}$ represents the vector of forces and moments of the control inputs; and

$v_{\mathrm{r}}$ is the relative speed of the vehicle regarding the sea currents.

In the case of vehicles navigating through the surface, the $g(\eta)$ vector is considered as zero. The structure of each one of these matrices and vectors for the Krick Felix vehicle has been determined by the GARP in previous researches (Valeriano, García, \& Balanza, 2017).

The $\mathrm{v}_{\mathrm{r}}$ term represents the relative speed of the vehicle regarding the sea currents (8) and it is defined as follow:

$$
\mathrm{v}_{\mathrm{r}}=\mathrm{V}-\mathrm{v}_{\mathrm{c}}
$$

where,

$\mathrm{v}$ is the vehicle vector speed defined in equation (1); and $\mathrm{v}_{\mathrm{c}}=\left[\mathrm{u}_{\mathrm{c}}, \mathrm{v}_{\mathrm{c}}, 0\right]^{\mathrm{T}}$ is the vector representing the speed of the sea currents relative to the origin of the vehicle system, by considering that those currents do not generate rotational movements in the boat.

The components $\mathrm{u}_{\mathrm{c}}$ and $\mathrm{v}_{\mathrm{c}}$ relative to the inertial system can be calculated through the speed module of the currents $\left(V_{C}\right)$ and through the direction angle they have $\left(\beta_{\mathrm{c}}\right)$ :

$$
\begin{gathered}
u_{c}^{E}=V_{C} \cos \beta_{c} \\
v_{c}^{E}=V_{C} \operatorname{sen} \beta_{c}
\end{gathered}
$$

In order to obtain the components relative to the $O_{b}$, it is necessary to apply the coordinate transformations in function of the Euler angles (Fossen, 2011), as shown in (11).

$$
\left[\begin{array}{l}
u_{c} \\
v_{c}
\end{array}\right]=\left[\begin{array}{cc}
\cos \psi & \sin \psi \\
-\sin \psi & \cos \psi
\end{array}\right]\left[\begin{array}{l}
u_{c}^{E} \\
v_{c}^{E}
\end{array}\right]
$$


After, applying trigonometric identities, it is possible to develop equations (12) and (13) as follow:

$$
\begin{aligned}
& u_{c}=V_{C} \cos \left(\beta_{c}-\psi\right) \\
& v_{c}=V_{C} \sin \left(\beta_{c}-\psi\right)
\end{aligned}
$$

The expressed model in equation (7) is the most accurate mathematical representation of the vehicle and it is the one employed by us in the simulation to assess the performance of the guidance scheme.

\section{Linear Model for the Lateral Subsystem}

In order to achieve in a surface vehicle maneuvers in environments where the sea perturbations are constant, it is not very practical to use a detailed model of the ship. Consequently, Equation (7) is not useful for the design of conventional and uncoupled controllers in a USV. Nevertheless, there is an alternative consisting of dividing the system in subsystems with low interaction. The objective of this option is to achieve faster simulation speeds than with the real-time maneuvers, which are especially important for dynamic prediction purposes (Fossen, 2002; Sutulo, Moreira, $\&$ Guedes, 2002). This decomposition is possible due to the geometric properties and the high symmetry grade that the employed vehicle has.

The two subsystems conforming the three degrees of liberty model of the Krick Felix and their corresponding state variables are:

- the lateral subsystem, employed for the maneuvers relative to drive the vehicle (state variables: $v, r$ y $\psi$ ); and

- the speed subsystem, used for the design of the speed controller (state variable: $u$ ).

From the uncoupled expressions describing the surge, sway, and yaw of the boat, it is possible to obtain the following movement linear equations (Chávez, Picado, \& Steller, 2005): speed (14), sway (15) and yaw (16).

$$
\begin{aligned}
& X=m\left(\dot{u}-v_{r}-X_{G r^{2}}\right) \\
& Y=m\left(\dot{v}-u_{r}-X_{G \dot{r}}\right) \\
& N=I_{Z} r \dot{+}+m X_{G \dot{r}}\left(u_{r}+\dot{v}\right)
\end{aligned}
$$

Equation (14) - longitudinal movement - can be uncoupled from the other two - transversal movement and yawby supposing that the ship speed and the thrust are constant.

In this research, the lateral subsystem is the one with larger interest, since it is the one employed for the design of the direction controller; this latter receives the references from the guidance system. As per the origin of the coordinate system of the Krick Felix ship is located in the center of gravity, the term $X_{G}$ is zero. Considering these elements,
El modelo expresado mediante la Ecuación (7) constituye la representación matemática más exacta del vehículo, por lo cual se emplea en la simulación para evaluar el desempeño del esquema de guiado.

\section{Modelo lineal para el subsistema lateral}

Para que un vehículo de superficie realice diversas maniobras en entornos donde las perturbaciones marinas son afectaciones constantes, resulta poco práctico el uso de un modelo detallado de la embarcación, por ello, la Ecuación (7) no resulta útil para el diseño de controladores convencionales y desacoplados en un USV. Sin embargo, existe una alternativa que consiste en dividir el sistema en subsistemas entre los cuales exista poca interacción. El objetivo de esta opción es alcanzar mayor rapidez en las simulaciones que en las maniobras de tiempo real, lo cual es especialmente importante para propósitos de predicción dinámica (Fossen, 2002; Sutulo, Moreira, \& Guedes, 2002). Esta descomposición es posible debido a las propiedades geométricas y al alto grado de simetría con que cuenta el vehículo con el cual se trabaja.

Los dos subsistemas en los que se divide el modelo de 3 GDL del Krick Felix y sus variables de estado son:

- el subsistema lateral, utilizado para las maniobras de dirección del vehículo (variables de estado: v, ry $\psi$ ); y

- el subsistema de velocidad, utilizado para el diseño del controlador de velocidad (variable de estado: $u$ ).

De las expresiones desacopladas que describen el movimiento de avance, el desplazamiento lateral y la guiñada de la embarcación, se puede obtener las siguientes ecuaciones lineales del movimiento (Chávez, Picado, \& Steller, 2005): velocidad (14), desplazamiento lateral (15) y guiñada (16).

$$
\begin{aligned}
& X=m\left(\dot{u}-v_{r}-X_{G r^{2}}\right) \\
& Y=m\left(\dot{v}-u_{r}-X_{G \dot{r}}\right) \\
& N=I_{Z} r+m X_{G \dot{r}}\left(u_{r}+\dot{v}\right)
\end{aligned}
$$

La ecuación (14) - movimiento longitudinal- se puede desacoplar de las otras dos - movimiento transversal y guiñada-, suponiendo que la velocidad del barco u y el empuje se mantienen constantes.

En esta investigación, el subsistema lateral es el de mayor interés, puesto que es el utilizado para el diseño del controlador de rumbo, el cual recibe las referencias provenientes del sistema de guiado. Como el origen del sistema de coordenadas del barco Krick Felix se encuentra ubicado en el centro de gravedad, el término $X_{G}$ es igual a cero. Teniendo en cuenta estos elementos, la dinámica del vehículo para el subsistema lateral se puede describir a partir de las ecuaciones (17) y (18).

$$
\begin{aligned}
& Y=m\left(\dot{v}-u_{0} r\right) \\
& N=I_{Z} \dot{r}
\end{aligned}
$$

La relación de transformación cinemática correspondiente al término, teniendo en cuenta las condiciones de operación del vehículo, está definida por la ecuación (19). 


$$
\dot{\psi}=\frac{s \theta_{0}}{c \theta_{0}} q+\frac{c \phi_{0}}{c \theta_{0}} q=r
$$

Las expresiones correspondientes a $\Upsilon_{\text {y }} \mathcal{N}$ para este subsistema son:

$$
\begin{aligned}
& Y=m\left(\dot{v}-u_{0} r\right) \\
& N=I_{Z} \dot{r}
\end{aligned}
$$

El modelo lineal en espacio-estado que representa la dinámica del subsistema lateral está dado por:

$$
\left[\begin{array}{l}
\dot{v} \\
\dot{r} \\
\dot{\psi}
\end{array}\right]=\left[\begin{array}{ccc}
\frac{Y_{v}}{m-Y_{\dot{v}}} & \frac{m u_{0}}{m-Y_{\dot{v}}} & 0 \\
0 & \frac{N_{r}}{I_{z}-N_{\dot{r}}} & 0 \\
0 & 1 & 0
\end{array}\right]\left[\begin{array}{l}
v \\
r \\
\psi
\end{array}\right]+\left[\begin{array}{c}
\frac{b_{2}}{m-Y_{\dot{v}}} \\
\frac{b_{3}}{I_{z}-\hat{\psi}_{\dot{\psi}}} \\
0
\end{array}\right] \delta_{T}
$$

donde,

$Y_{\dot{v}}$ y $N_{\dot{r}}$ son la fuerza y el momento provocados por las masas añadidas;

$\mathcal{Y}_{v}$ y $\mathcal{N}_{r}$ poseen valores negativos ya que son la fuerza y el momento de amortiguamiento; $y$

$b_{2}$ y $b_{3}$ son ganancias a partir de las cuales se generan la fuerza y el momento provocados por el timón.

El modelo de Nomoto de segundo orden es una alternativa muy utilizada por los diseñadores de los sistemas de control para obtener modelos de orden reducido basados en el subsistema lateral (Fossen, 2011; Moreno, Besada, López, Chaos, Aranda, \& Cruz, 2015). A partir de este modelo, es posible obtener la función de transferencia entre el ángulo de guiñada y el ángulo de deflexión del timón horizontal como:

$$
\frac{\psi(s)}{\delta_{T}(s)}=\frac{b_{3}}{\left(I_{z}-N_{\dot{r}}\right) s^{2}-N_{r} s}=\frac{0.0437}{0.1945 s+1}
$$

\section{Controlador de rumbo}

Este tipo de controlador tiene como objetivo seguir las referencias que le son suministradas por el algoritmo de guiado (Valeriano et al., 2015). El controlador de rumbo que se ha seleccionado en este trabajo es del tipo P-D, debido a que la acción derivativa provee un margen de fase adicional que aumenta la robustez del mismo (Jalving \& Storkersen, 1995).

La Ecuación (23) describe de manera simplificada la dinámica lateral del Krick Felix.A partir de esta función de transferencia se ajusta el controlador, cuya señal de mando se presenta a continuación:

donde,

$$
\delta_{T}=K_{p}\left(\psi_{d}-\psi\right)-K_{d} r
$$

$K_{p}$ y $K_{d}$ representan los valores de ganancia proporcional y derivativa respectivamente; $y$

el valor de $\psi_{d}$ es usado para denotar el ángulo de dirección deseado, el cual proviene del algoritmo de guiado en función de la ruta que se desea seguir. the dynamics of the vehicle for the lateral subsystem can be described from equations (17) and (18).

$$
\begin{aligned}
& Y=m\left(\dot{v}-u_{0} r\right) \\
& N=I_{Z} \dot{r}
\end{aligned}
$$

The kinematic transformation relation corresponding to the term by considering the operation conditions of the vehicle is defined by Equation (19).

$$
\dot{\psi}=\frac{s \theta_{0}}{c \theta_{0}} q+\frac{c \phi_{0}}{c \theta_{0}} q=r
$$

The expressions corresponding to $Y$ and $\mathcal{N}$ for this subsystem are:

$$
\begin{aligned}
& Y=m\left(\dot{v}-u_{0} r\right) \\
& N=I_{Z} \dot{r}
\end{aligned}
$$

The linear model in space-state representing the dynamics of the lateral subsystem is provided by:

$$
\left[\begin{array}{l}
\dot{v} \\
\dot{r} \\
\dot{\psi}
\end{array}\right]=\left[\begin{array}{ccc}
\frac{Y_{v}}{m-Y_{\dot{v}}} & \frac{m u_{0}}{m-Y_{\dot{v}}} & 0 \\
0 & \frac{N_{r}}{I_{z}-N_{\dot{r}}} & 0 \\
0 & 1 & 0
\end{array}\right]\left[\begin{array}{l}
v \\
r \\
\psi
\end{array}\right]+\left[\begin{array}{c}
\frac{b_{2}}{m-Y_{\dot{v}}} \\
\frac{b_{3}}{I_{z}-N_{\dot{r}}} \\
0
\end{array}\right] \delta_{T}
$$

where,

$\mathcal{Y}_{\dot{v}}$ and $\mathcal{N}_{\dot{r}}$ are the force and movement causedby the added masses;

$\Upsilon_{v}$ and $\mathcal{N}_{r}$ have negative values, since they are the damping force and moment; and

$b_{2}$ and $b_{3}$ are gains generating the force and moment triggeredby the rudder.

The second-order Nomoto model is a widely employed alternative for control system developers to obtain low-order models in the lateral subsystem (Fossen, 2011; Moreno, Besada, López, Chaos, Aranda, \& Cruz, 2015). From this model, it is possible to obtain the transfer function between the yaw angle and the horizontal deflection angle of the rudder as follow:

$$
\frac{\psi(s)}{\delta_{T}(s)}=\frac{b_{3}}{\left(I_{z}-N_{\dot{r}}\right) s^{2}-N_{r} s}=\frac{0.0437}{0.1945 s+1}
$$

\section{Heading Controller}

The main objective of this controller type is to follow the references supplied by the guidance algorithm (Valeriano et al., 2015). The direction controller selected in this work is from the P-D type, since the derivative action provides an 
additional phase range, increasing its robustness (Jalving \& Storkersen, 1995).

Equation (23) describes - in a simplified manner - the lateral dynamic of the Krick Felix. From this transfer function, the controller is adjusted. We present the control signal as follow:

$$
\delta_{T}=K_{p}\left(\psi_{d}-\psi\right)-K_{d} r
$$

where,

$K_{p}$ and $K_{d}$ represent the proportional and derivative gain, respectively; and

the $\psi_{d}$ value is employed to denote the desired direction angle, which comes from the guidance algorithm in function of the desired path to follow.

The adjustment is performed using the poles and zeros location technique in the tool. The obtained gain values are $K_{p}=10$ and $K_{d}=1$.

\section{I-LOS Controller}

For the case of the path following feature, where only spatial restrictions are important, the objective of the guidance law is focused on the vehicle convergence to the straight path; hence, path following errors associated to the vehicle convergence to the road arose, as Figure 3 shows. Let $x_{e}(t)$ the path following error through the road and $y_{e}(t)$ the path following error perpendicular to the road. Their expressions are shown below.

$$
\begin{aligned}
& x_{e}(t)=\left(x_{t}-x_{k}\right) \cos \alpha_{k}+\left(y_{t}-y_{k}\right) \sin \alpha_{k} \\
& y_{e}(t)=-\left(x_{t}-x_{k}\right) \sin \alpha_{k}+\left(y_{t}-y_{k}\right) \cos \alpha_{k}
\end{aligned}
$$

In order to counteract the deviation triggered by the sea currents during the path following of straight roads, it is necessary to define the following control objective:

$$
\lim (t \rightarrow \infty) y_{e}(t)=0
$$

We propose to use a controller with integral action to achieve this objective by taking the lateral sliding angle caused by the sea currents as a small perturbation of low variation, i.e., $\beta_{r} \approx 0$.

It is necessary to define the following to employ these variants:

$$
\psi_{d}\left(y_{e}\right)=\chi\left(y_{e}\right)+\beta_{r}
$$

By adopting the mentioned consideration, equation (28) can be rewritten as follow:

$$
\psi_{d}\left(y_{e}\right)=\chi\left(y_{e}\right)
$$

The desired direction value must coincide with the curse angle $\chi\left(y_{e}\right)$, which is calculated through equation (30).

$$
\chi\left(y_{e}\right)=\chi_{r}\left(y_{e}\right)+\chi_{p}
$$

El ajuste se realiza utilizando la técnica de ubicación de polos y ceros. Los valores obtenidos de ganancia son $K_{p}=10$ y $K_{d}=1$.

\section{Controlador I-LOS}

Para el caso de seguimiento de caminos, donde interesan solo las restricciones espaciales, el objetivo de la ley de guiado se centra en la convergencia del vehículo al camino recto, por lo que surgen entonces errores de seguimiento asociados a la convergencia del vehículo al camino, como se muestra en la Figura 3, dígase el error de seguimiento a lo largo del camino $\left(\mathrm{x}_{e}(t)\right)$ y el error de seguimiento perpendicular al camino $\left(\mathrm{y}_{\mathrm{e}}(t)\right)$, cuyas expresiones se muestran a continuación:

$$
\begin{aligned}
& x_{c}(t)=\left(x_{t}-x_{k}\right) \cos \alpha_{k}+\left(y_{t}-y_{k}\right) \sin \alpha_{k} \\
& y_{c}(t)=-\left(x_{t}-x_{k}\right) \sin \alpha_{k}+\left(y_{t}-y_{k}\right) \cos \alpha_{k}
\end{aligned}
$$

Para contrarrestar la desviación provocada por las corrientes marinas durante el seguimiento de caminos en línea recta es necesario definir el siguiente objetivo de control:

$$
\lim (t \rightarrow \infty) y_{e}(t)=0
$$

Para lograr este objetivo se propone utilizar un controlador con acción integral, tomando el ángulo de deslizamiento lateral provocado por las corrientes marinas como una perturbación pequeña de poca variación, es decir $\beta_{r} \approx 0$.

Para llevar a cabo estas variantes es necesario definir:

$$
\psi_{d}\left(y_{e}\right)=\chi\left(y_{e}\right)+\beta_{r}
$$

$\mathrm{Al}$ adoptar la consideración mencionada, la ecuación (28) se puede reescribir de la siguiente manera:

$$
\psi_{d}\left(y_{e}\right)=\chi\left(y_{e}\right)
$$

El valor de rumbo deseado debe coincidir con el ángulo de curso $\chi\left(\mathrm{y}_{\mathrm{e}}\right)$, el cual se calcula apartir de la ecuación (30).

$$
\chi\left(y_{e}\right)=\chi_{r}\left(y_{e}\right)+\chi_{p}
$$

donde,

$$
\begin{gathered}
\chi_{p}=\alpha_{k} \\
\chi_{r}\left(y_{e}\right)=-\tan ^{-1}\left(k_{p} y_{e}(t)+k_{i} y_{\text {int }}\right)
\end{gathered}
$$

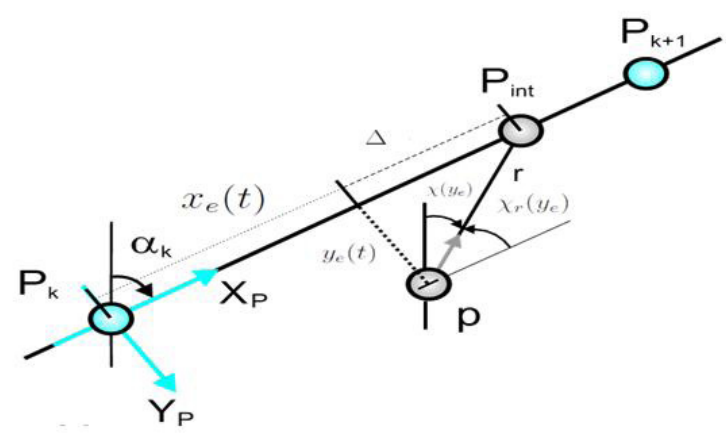

Figure 3. Main variables of the guidance algorithm based on the look-ahead distance / Principales variables del algoritmo de guiado basado en la distancia look ahead 
donde,

$\chi_{p}$ es el ángulo tangente al camino, y

$\chi_{r}\left(y_{e}\right)$ es un ángulo de corrección que asegura que la velocidad del vehículo esté en dirección al punto del camino hacia el cual la embarcación se dirige,

y por su parte,

$k_{i}=k_{y} k_{p}$, siendo $k_{\mathrm{y}}>0$ un parámetro de diseño,

$$
\begin{aligned}
& y_{\text {int }}^{\cdot}=\frac{y \Delta}{(\Delta)^{2}\left(y+k_{y} y_{\text {int }}\right)^{2}} \\
& k_{p}=\frac{1}{\Delta}
\end{aligned}
$$

El parámetro $\Delta$ está asociado a la distancia look ahead que es la distancia que existe entre la proyección de la posición del vehículo sobre el camino y el punto del camino al cual se dirige la embarcación. Este parámetro puede ser variable o constante y su selección está asociada a la longitud del vehículo - de dos a seis veces dicha longitud-. Para el caso de esta investigación este valor se toma constante.

Para considerar que un punto del camino ha sido vencido se propone una vía para hacerlo, la cual está asociada a un círculo de aceptación que se establece con cada punto del camino, cuyo radio sería de valor $R_{(k+1)}$ $>0$ para el punto del camino $k+1$, de manera tal que el criterio para que el vehículo cambie de dirección hacia el siguiente punto queda definido por la ecuación (35):

$$
\left(x_{k+1}-x(t)\right)^{2}+\left(y_{k+1}-y(t)\right)^{2} \leq R_{k+1}^{2}
$$

Por lo que, para cambiar de punto resulta necesario que la posición del vehículo esté dentro de la esfera de aceptación, teniendo que definir un valor de $R_{(k+1)}$.

\section{Resultados de simulaciones}

Para validar el método propuesto es necesario primero definir el camino que se desea que el vehículo recorra. Este camino está compuesto por dos puntos con las coordenadas (x,y) como se muestra en la TABLA 3. Cabe aclarar que el vehículo parte desde la posición $[\mathrm{x}, \mathrm{y}]^{\mathrm{T}}=[20,5]^{\mathrm{T}}$ con un ángulo de rumbo $=0^{\circ}$.

Para recrear en simulación las condiciones de operación típicas del vehículo se utilizaron los siguientes datos: velocidad de las corrientes marinas, $V_{C}=0.1 \mathrm{~m} / \mathrm{s}$ y ángulo de dirección de las corrientes marinas, $\beta_{c}=10^{\circ}$. Por su parte, la velocidad de giro del motor del Krick Felix se fijó en $600 \mathrm{rpm}$ y el período de muestreo para las simulaciones en $T=0,01$ s. Durante la simulación se estableció el valor de ganancia del controlador $k_{y}=$ $0.5 \mathrm{~m} / \mathrm{s}$. Una vez fijados estos parámetros se evaluó el resultado de las simulaciones para varios valores de $\Delta$ y se pudo comprobar que la mejor respuesta se obtiene con un valor de $\Delta=2$, dado que este valor se encuentra en el rango de dos a seis veces la longitud el vehículo y permite que el error perpendicular al where,

$$
\begin{gathered}
\mathrm{X}_{\mathrm{p}}=\alpha_{\mathrm{k}} \\
\chi_{\mathrm{r}}\left(\mathrm{y}_{\mathrm{e}}\right)=-\tan ^{-1}\left(\mathrm{k}_{\mathrm{p}} \mathrm{y}_{\mathrm{e}}(\mathrm{t})+\mathrm{k}_{\mathrm{i}} \mathrm{y}_{\text {int }}\right)
\end{gathered}
$$

where,

$\chi_{p}$ is the tangent angle to the road;

$\chi_{r}\left(y_{e}\right)$ is a correction angle that ensures the vehicle speed is pointed to the path where the boat goes; and,

$k_{i}=k_{y} k_{p}$, being $k_{y}>0$ a design parameter,

$$
\begin{aligned}
& y_{\text {int }}^{\prime}=\frac{y \Delta}{(\Delta)^{2}\left(y+k_{y} y_{\text {int }}\right)^{2}} \\
& k_{p}=\frac{1}{\Delta}
\end{aligned}
$$

The $\Delta$ parameter is associated to the look-ahead distance, which is the distance existing between the projection of the vehicle position in the road and the point of the road where the boat goes. This parameter can be variable or constant and its selection is associated to the vehicle length - two to six times that length-. For the case of this research, we considered this value as constant.

To consider that a point in the road has been surpassed, we propose a procedure to do it, which is associated to an acceptance circle established for each point in the road. Its radio would be $R_{(k+1)}>0$ for the $k+1$ point; hence, the criterium to change the vehicle direction towards the next point is defined by equation (35):

$$
\left(x_{k+1}-x(t)\right)^{2}+\left(y_{k+1}-y(t)\right)^{2} \leq R_{k+1}^{2}
$$

Consequently, to producea point change, it is necessary that the vehicle position is within the acceptance sphere, making it required to define a $R_{(k+1)}$ value.

\section{Simulation Results}

To validate the proposed method, it is indispensable to define the desired path for the vehicle. This path is composed of two points with coordinates $(\mathrm{x}, \mathrm{y})$ as TABLE 3 shows. It is important to focus that the vehicle starts from the position $[\mathrm{x}, \mathrm{y}]^{\mathrm{T}}=[20,5]^{\mathrm{T}}$ with a heading angle $=0^{\circ}$.

\begin{tabular}{ccc} 
Table 3. Points in the path / Puntos en el camino \\
\hline $\mathrm{X}(\mathrm{m})$ & 10 & 90 \\
$\mathrm{Y}(\mathrm{m})$ & 10 & 50
\end{tabular}

To recreate the typical operation conditions of the vehicle in our simulations, we used the following data: speed of the sea currents, $V_{C}=0.1 \mathrm{~m} / \mathrm{s}$; and direction angle of the sea currents, $\beta_{c}=10^{\circ}$. Similarly, the turn speed of the Krick Felix engine was set to $600 \mathrm{rpm}$ and the sampling period for the simulations is $T=0.01 \mathrm{~s}$. During the simulations, we also set the controller gain value, $k_{y}=0.5 \mathrm{~m} / \mathrm{s}$. Once these 
parameters are set, we assessed the simulation results for several $\Delta$ values and we confirmed that the best response was obtained with $\Delta=2$. This because of the fact that this value is within the range of two and six times the length of the vehicle; allowing that the perpendicular error to the road is quickly stabilized to zero and without oscillations, as the reader might observe in Figure 4.

Once the parameters are adjusted to make that the error

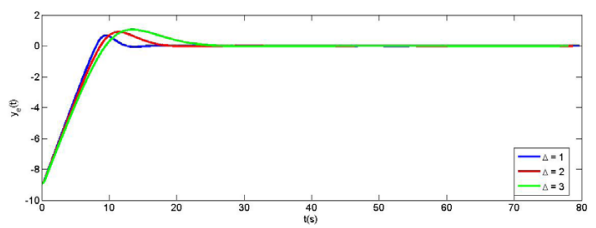

Figure 4. Perpendicular error to the road / Error perpendicular al camino

caused by the sea currents tends to zero, it is necessary to check that the vehicle can perform the following of the defined path, as Figure 5 shows.

The set-up effectiveness is assessed via simulations by varying the sea currents speed influencing the vehicle. The objective of these tests is to demonstrate that the adjusted I-LOS controller can minimize the $y_{e}(t)$ error when several sea currents speeds are present. The simulations were performed under the same conditions described for the controller set-up by considering the speeds of the sea currents, $\left[\mathrm{V}_{\mathrm{C}}\right]$ as $0.1,0.6$, and $1 \mathrm{~m} / \mathrm{s}$, respectively.

The result of the performed tests is presented in Figure 6, where the reader might see that, for the elevated values of the sea current speeds (i.e., $\left.y_{e}(t)\right)$, the error grows; nonetheless, the integral action in all the cases makes it to tend to zero.

\section{Conclusions}

The I-LOS guidance scheme ensures the vehicle convergence to the path. With the inclusion of an integral action inside the guidance law, we ensure a reduction in the perpendicular path following error caused by the sea currents effect within it.

The mathematical structure defined in the I-LOS controller is easy to be implemented and it also considers the windup effect, caused by an integral action. The controller gain calculation depends mainly of the selection in the look-ahead distance, which is considered constant and dependent of the vehicle length.

The simulation results indicate the viability of using this scheme type in the Krick Felix robotic boat.ST camino se estabilice en cero de forma rápida y sin presentar oscilaciones, como se puede apreciar en la Figura 4. Una vez que se ajustan los parámetros con el fin de llevar a cero el error provocado por las corrientes, es necesario comprobar que el vehículo es capaz de realizar el seguimiento del camino definido, como se muestra en la Figura 5.

La efectividad del ajuste se evalúa mediante simulación, variando la velocidad de las corrientes a las que se encuentra sometido el vehículo. El objetivo de estas pruebas es demostrar que el controlador I-LOS ajustado es capaz de minimizar el error $y_{e}(t)$ ante distintos valores de velocidad de las corrientes. Las simulaciones se realizaron bajo las mismas condiciones descritas para el ajuste del controlador, tomando como valores para la velocidad de las corrientes $\left[\mathrm{V}_{\mathrm{C}}\right] \quad 0.1,0.6$ y $1 \mathrm{~m} / \mathrm{s}$, respectivamente.

El resultado de las pruebas realizadas se presenta en la FiguRA 6, donde se muestra que para los valores más elevados de la velocidad de las corrientes $y_{e}(t)$ incrementa su valor, pero la acción integral en todos los casos logra que se estabilice en cero.

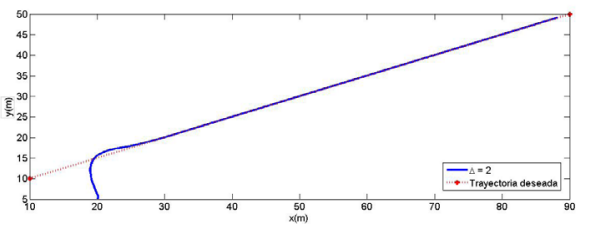

Figure 5. Path following for $\Delta=2 /$ Seguimiento del camino para $\Delta=2$

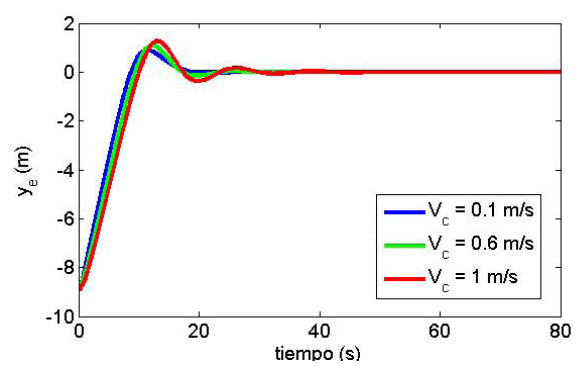

Figure 6. Perpendicular error to the road with variations in the sea current speeds / Error perpendicular al camino con variación de la intensidad de las corrientes

\section{Conclusiones}

El esquema de guiado I-LOS asegura la convergencia del vehículo al camino. Con la inclusión de una acción integral dentro de la ley de guiado se asegura una disminución del error de seguimiento perpendicular al camino provocado por el efecto de las corrientes marinas sobre el vehículo.

La estructura matemática definida en el controlador I-LOS es de fácil implementación y tiene en cuenta el efecto windup que se produce debido a la acción integral. El cálculo de las ganancias del controlador depende fundamentalmente de la selección del valor de la distancia look ahead, la cual se considera constante y dependiente de la longitud del vehículo.

Los resultados de las simulaciones realizadas demuestran la viabilidad de utilizar este tipo de esquema en el barco robótico Krick Felix.SST 


\section{References / Referencias}

Breivik, M. \& Fossen, T. (2009). Guidance laws for autonomous underwater vehicles. In: A. V. Inzartsev (Ed.), Underwater vehicles (pp. 51-76). Vienna, Austria: InTech.

Chávez, J., Picado, A., \& Steller, J. M. (2005). Aplicaciones de control en barcos [thesis]. Universidad de Costa Rica: San José.

Fossen, T. (1994). Guidance and control of ocean vehicles. Chichester, UK: John Wiley \& Sons.

Fossen, T. (2002). Guidance, navigation, and control of ships, rigs and underwater vehicles. Trondheim, Norway: Marine Cybernetics.

Fossen, T. \& Ross, A. (2006). Nonlinear modelling: Identification and control of UUVs. In: G.N. Roberts \& R. Sutton (Eds.), Advances in unmanned marine vehicles (pp. 13-42). London, UK: IET

Fossen, T. (2011). Handbook of marine craft hydrodynamics and motion control. Chichester, UK: John Wiley \& Sons.

Hernández, A., Valeriano-Medina, Y. \& Fernández, J. (2016). Control I-LOS considerando la distancia lookahead constante para el seguimiento de camino curvos en AUV [2016 Convención Científica de Ingeniería y Arquitectura, La Habana, Cuba].

Jalving, B. \& Storkersen, N. (1995). The control system of an autonomous underwater vehicle. Modeling, Identification and Control, 15, 107-117.

Lekkas, A. M. (2014). Guidance and path-planning systems for autonomous [thesis]. NTNU: Ålesund, Norway. Available at: https://brage.bibsys.no/xmlui/handle/11250/261188

Miranda, L., Valeriano-Medina, Y. \& Hernández, A. (2017). Sistema de guiado desacoplado en 3D para el vehículo HRCAUV [2017 Convención Internacional 2017 Universidad Central "Marta Abreu" de Las Villas. XVII Simposio de Ingeniería Eléctrica].

Moreno, D., Besada, E., López, J. A., Chaos, D., Aranda, J. \& Cruz, J. M. (2015). Identificación de un modelo no lineal de un vehículo marino de superficie usando regresión simbólica. In Actas de las Jornadas de Automática 2015 (pp. 850-855). Bilbao, España: IFAC.

Sutulo, S., Moreira, L. \& Guedes, C. (2002). Mathematical models for ship path prediction in maneuvering simulation systems. Ocean Engineering, 29(1), 1-19. doi:10.1016/S0029-8018(01)00023-3

Valeriano-Medina, Y., García, D. \& Balanza, C. (2017). Modelado dinámico del barco de pequeño porte Krick Felix. [2017 Convención Internacional 2017 Universidad Central "Marta Abreu" de Las Villas . XVII Simposio de Ingeniería Eléctrica].

Valeriano-Medina, Y., Hernández-Julián, A. \& Hernández, L. (2015). Controlador I-LOS para el seguimiento de caminos en línea recta de un vehículo autónomo subacuático. Revista de Ingeniería Electrónica, Automática y Comunicaciones, 36(2), 15-28. 


\section{CURRICULUM VITAE}

Leidys Miranda Jiménez Automation Engineer from the Universidad Central "Marta Abreu" de las Villas [UCLV] (Cuba, 2016) and professor at the Department of Automatics and Computational Systems of the Faculty of Engineering of said university. He is a member of the Automation, Robotics and Perception Group [GARP]. His areas of professional interest include the modeling, control and guidance of unmanned vehicles and robotics / Ingeniera en Automática de la Universidad Central "Marta Abreu" de las Villas [UCLV] (Cuba, 2016) y docente del Departamento de Automática y Sistemas Computacionales de la Facultad de Ingeniería de dicha universidad. Es miembro del Grupo de Automatización, Robótica y Percepción [GARP]. Sus áreas de interés profesional incluyen el modelado, control y guiado de vehículos no tripulados y la robótica.

Yunier Valeriano Medina Doctor in Technical Sciences (2017), Master in Automation and Computer Systems (2013) and Automation Engineer from the Universidad Central "Marta Abreu" de Las Villas [UCLV] (Cuba, 2009). Researcher and professor at the Automation and Computer Systems Department of the Electrical Engineering Faculty of the UCLV, with nine years of experience. He is a member of the Automation, Robotics and Perception Group [GARP]. His research works have been awarded, among others, by the Cuban Academy of Sciences. His areas of interest include: theory and control systems; computer vision; mathematical modeling; dynamic; mechatronics; navigation; instrumentation; and guidance and control of unmanned vehicles / Doctor en Ciencias Técnicas (2017), Máster en Automática y Sistemas Informáticos (2013) e Ingeniero en Automática de la Universidad Central "Marta Abreu" de Las Villas [UCLV] (Cuba, 2009). Es docente investigador del Departamento de Automática y Sistemas Computacionales en la Facultad de Ingeniería Eléctrica de la UCLV, con nueve años de experiencia. Es miembro del Grupo de Automatización, Robótica y Percepción [GARP]. Sus trabajos de investigación han sido premiados, entre otros, por la Academia de Ciencias de Cuba. Sus áreas de interés incluyen: teoría y sistemas de control; visión por computador; modelado matemático; dinámica; mecatrónica; navegación; instrumentación; y guiado y control de vehículos no tripulados.

Ángel Alejandro Camero Álvarez Automation Engineer from the Universidad Central "Marta Abreu" de Las Villas (Cuba, 2018). His areas of professional interest include the modeling, control and guidance of unmanned vehicles and robotics / Ingeniero en Automática de la Universidad Central "Marta Abreu" de las Villas (Cuba, 2018). Sus áreas de interés profesional incluyen el modelado, control y guiado de vehículos no tripulados y la robótica. 